\title{
Casting the runes
}

\author{
Stuart Johnston \\ Chair, Dental Amalgam Task Team and Dental Practice Committee, \\ FDI World Dental Federation
}

\author{
Susie Sanderson OBE \\ Chair, Amalgam and Other Restorative Materials Working Group, \\ Council of European Dentists
}

The majority of dentists have used dental amalgam with reliability and success at some points in their careers. The mercury ingredient of amalgam has, however, for years attracted attention and until relatively recently interest centred around health risks - risks to those placing and receiving fillings containing mercury. Developing its 2005 Mercury Strategy, the European Commission asked its scientific committees to give opinions on health risks of amalgam and alternative materials and their environmental impacts. They reported that, 'dental health can be adequately ensured by both types of material. All materials are considered safe to use and they are all associated with very low rates of local adverse effects with no evidence of systemic disease ${ }^{, 1}$ and, "it is clear that the information presently available does not allow to comprehensively assessing ( $\mathrm{sic}$ ) the environmental risks and indirect health effects from use of dental amalgam in the Member States of the EU. ${ }^{2}$ These statements heralded the first insurgence into what we know now to be a complex agenda of interweaving factors.

\section{DENTISTS NEED THE FULL RANGE OF DENTAL MATERIALS}

The Council of European Dentists (CED), through its Amalgam Working Group, built constructive relationships at that time with the European Commission and its representations were welcomed and considered. CED insisted that dentists need available the full range of dental materials to make treatment decisions, with patients' consent, in their patients' best interests. A challenging dynamic for dentistry emerged gradually as mercury use was significantly eliminated in larger industries and amalgam surfaced into the spotlight as an easily picked off target. Hearing the rumours of the pressure to restrict the use of amalgam in Europe, CED also pointed out firmly to the Commission that member states' governments should enforce the Hazardous Waste Directive and that to implement properly designed and appropriately funded oral health improvement programmes would be sensible. Clearly a decline in a preventable disease like caries would reduce the need for interventions with any material. There was, we said, a fundamental attraction in resolving the cause of the problem rather than just substituting other dental materials for amalgam.

At that point, to coin a phrase, the situation went global. In February 2009, the Governing Council (GC) of the United
Nations Environment Programme (UNEP) agreed the need for a global legally binding instrument on mercury. The GC told governments worldwide to negotiate this treaty through a series of five conferences. The final Intergovernmental Negotiating Committee (INC) ${ }^{3}$ meeting will be held in January 2013. The treaty will include provisions specifically for dental amalgam, probably related to international guidance, which will be legally binding for signatories.

\section{COMMITMENT TO IMPROVING HEALTH AND ORAL HEALTH}

From the start of the INC process, the dental profession has contributed to the discussion. The FDI's Dental Amalgam Task Team (DATT), working alongside the International Association of Dental Research (IADR), has made sure that the debate covers the full complexity of the mechanisms of delivery and status of oral health worldwide. The FDI's advocacy toolkit ${ }^{4}$ reminds us: 'such an important decision about global oral health should not be compartmentalised within a narrow debate about individual products, but rather be comprehensive in its scope, and include a commitment to improving health and oral health, as well as protecting the environment.'

Informing both the INC process and the European Mercury Strategy developments is the seminal 2010 World Health Organisation (WHO) Experts Consultation report on 'Future use of materials for dental restoration. ${ }^{5}$ While the document is not without its critics, it makes several important conclusions and recommendations that have received general support. Notably, it concludes that there is no current replacement for amalgam and recommends a 'phasing down' instead of 'phasing out' of dental amalgam at this stage. Alongside that it introduces the principle of the environmentally sound lifecycle management (ESLM) of all dental materials.

And so we stumble headlong into the realisation that dentistry is not the tiny parochial ring-fenced discipline we had always thought we owned. The authors are frequently asked how the amalgam situation will resolve. We can merely cast the runes and in doing so we cannot actually see the future. Instead, runes give us a means of analysing the path that we are on and a likely outcome. The future is not fixed. It changes with everything we do. We have already demonstrated that, by committing responsibly to taking the Hazardous Waste legislation seriously and supporting dental materials research, 
we are welcomed, albeit cautiously, to the negotiating table. And we find ourselves on a spaghetti junction of mammoth proportions. The Basel $^{6}$, Rotterdam ${ }^{7}$, Stockholm $^{8}$ and Vienna ${ }^{9}$ Conventions all have national implications for dentistry. As it seeks to define its role in health, the Strategic Management of International Chemicals Management (SAICM) ${ }^{10}$ policy framework almost certainly will have an interest in dentistry - we commonly use materials which contain or produce nanoparticles and endocrine disrupters.

\section{NON-COMMUNICABLE DISEASES}

At the other end of the mirror and probe, the profession is considering its integration with the wider health agenda. The emerging non-communicable diseases agenda highlights common risk factors - smoking, alcohol, diet, exercise. In the authors' minds, we should, day-to-day, be making real efforts to influence the social determinants of health. FDI's Global Caries Initiative (GCI) is a profession-led call to action and will succeed through broad alliances of key influencers and decision makers. Discussing the GCI, Fisher et al. say it is "our responsibility to deliver an effective, efficient and sustainable model of oral care based on the best available evidence, one that addresses health inequalities and improves health outcomes worldwide. ${ }^{, 11}$

European decisions will influence and be influenced by the UNEP INC conclusions. The recent BIOIS report ${ }^{12}$ was frustrating in its bias and superficiality. Again the Commission is seeking opinions of its scientific committees on a range of relevant issues to inform its next steps and future developments. The 'phase down' route is favoured currently and restrictions of amalgam, with hinted at significant exceptions, will probably swiftly be upon us. We are a responsible profession and we want the best for our patients. Our politicians must seize the opportunities of facilitating the right paths on behalf of their populations though - we can't do it on our own.

1. European Commission Scientific Committee on Emerging and Newly Identified Health Risks. The safety of dental amalgam and alternative dental restoration materials for patients and users. http://ec.europa.eu/health/ph_risk/committees/04_scenihr/docs/scenihr_o_016.pdf (accessed Oct 2012).

2. European Commission Scientific Committee on Health and Environmental Risks. Opinion on the environmental risks and indirect health effects of mercury in dental amalgam. http://ec.europa.eu/health/ph_risk/committees/04_scher/docs/ scher_o 089.pdf (accessed Oct 2012).

3. UNEP Intergovermental Negotiating Committee. INC4 meeting report. www.unep org/hazardoussubstances/Mercury/Negotiations/INC4/tabid/3470/Default.aspx (accessed Oct 2012).

4. FDI World Dental Federation Library. www.fdiworldental.org/library (accessed Oct 2012).

5. World Health Organisation. Future use of materials for dental restoration. Geneva, Switzerland: WHO, 2009

6. Basel Convention. www.basel.int (accessed Oct 2012).

7. UNEP. Rotterdam convention on the prior informed consent procedure for certain hazardous chemicals and pesticides in international trade. www.pic.int/TheConvention/Overview/TextoftheConvention/tabid/1048/language/n-US/Default.aspx (accessed Oct 2012).

8. UNEP. Stockholm convention on persistent organic pollutants. http://chm.pops. int/Convention/ConventionText/tabid/2232/Default.aspx (accessed Oct 2012).

9. United Nations Environment Programme: Ozone Secretariat. http://ozone.unep. org/new_site/en/index.php

10. UNEP. Strategic approach to international chemicals managment (SAICM). www.SAICM.org (accessed Oct 2012).

11. Fisher J, Johnston $\mathrm{S}$, Hewson $\mathrm{N}$ et al. FDI Global Caries Initiative; implementing a paradigm shift in dental practice and the global policy context. Int Dent J 2012; 62: $169-174$

12. European Commission. Review of the community strategy concerning mercury. http://ec.europa.eu/environment/chemicals/mercury/pdf/review_mercury_ strategy2010.pdf (accessed Oct 2012).

DOI: 10.1038/sj.bdj.2012.893 